\title{
Assessment of a Precaution Index for Environmental Evaluation: An Example of Application to the Cow's Milk Production
}

\author{
Francesca Ventura*, Marco Vignudelli, Linda Pieri, Paola Rossi Pisa \\ Department of Agricultural Sciences, University of Bologna, Bologna, Italy \\ Email: ${ }^{*}$ Francesca.ventura@unibo.it
}

Received 6 February 2014; revised 6 March 2014; accepted 12 March 2014

Copyright (C) 2014 by authors and Scientific Research Publishing Inc.

This work is licensed under the Creative Commons Attribution International License (CC BY). http://creativecommons.org/licenses/by/4.0/

(c) (i) Open Access

\begin{abstract}
The paper presents a Precaution Index (P) developed to create an instrument to assess the potential risk related to the presence of pollution sources next to milk production farms. The methodology starts from the inventory and geo-referencing of all pollution sources in an area, with the help of the multi-criteria decision analysis. Results are represented in a map of $P$, which highlights which areas are most at risk and need monitoring, and which pollutants may be involved. This may help in the early identification of emerging hazards to food safety. P was calculated for the milk production in an Italian region. Results show that $97 \%$ of the area is in a condition of minimum precaution that would be needed in controlling the safety of dairy products.
\end{abstract}

\section{Keywords}

Environmental Pollution, Precaution Index, GIS, Multi-Criteria Analysis, Cow's Milk, Emilia-Romagna Region

\section{Introduction}

In recent times, the amount of Italian territory occupied by urban and industrial settlements, not to talk about roads and highways, has been increasing [1]. As a result, agricultural land adjacent to urban areas, the so-called "peri-urban" agriculture, is exposed increasingly to air pollutants of urban or industrial origins. Agricultural products are grown closer and closer to potential sources of pollutants, such as incinerators, power plants, highways, industrial factories, and so on, with the potential risk for their safety. Some of these pollutants can be considered a threat to crop production and cattle [2] for the significative yield losses and reduction safety of the

"Corresponding author.

How to cite this paper: Ventura, F., et al. (2014) Assessment of a Precaution Index for Environmental Evaluation: An Example of Application to the Cow's Milk Production. Food and Nutrition Sciences, 5, 857-869. 
products [3] [4]. Indeed peri-urban agriculture, and the potential risks to which it is subject, is a growing problem not only in Italy, but especially in countries with high population growth, such as in India, as reported by [5] [6].

Data about monitoring of single sources and their effects on environment or human health are widely available both in the scientific literature [7] [8] and at institutional web sites (e.g. European Pollutant and Release and Transfer Register, http://prtr.ec.europa.eu), but what is lacking and what we propose with this paper is a method to assess and treat all such information and data. A complete overview of the environmental situation of a territory highlights its critical points, hotspots, which means areas where there is a high concentration of sources of pollution, with negative consequences on environment matrixes (water, air, soil, etc.), agricultural products, livestock and, finally, the human health.

A map of the potential pollution risks provides very useful information both to the national and local authorities, and to farmers and companies. From the producers point of view this aspect is not negligible: on one hand, on the basis of potential risk, food products from large farms may be subjected to differentiated analysis of the quality. Given the high costs of analysis, this may bring to significant money savings and better results. On the other hand, when the products come from areas with certificated low risk of pollution, the company can use this information for advertising purposes. The benefits are numerous also for authorities: known the potential pollution risks, they can easily identify the hotspots and operate with specific monitoring on environmental matrixes. Therefore, the main aim of this work is not to provide a detailed description of the areas from the point of view of the risk of pollution, but orient the user (private companies, authorities, etc.), indicating the most critical situations. The user will evaluate whether or not to investigate further with due monitoring campaigns.

This approach is innovative, as demonstrated by the lack of specific scientific publications. Many publications discuss how agriculture can be a source of diffuse pollution [9]-[12], but it is not well stressed that the environment can cause adverse effects on agricultural and dairy products. This aspect of the food safety is rather neglected also in the European Union's (EU) food legislation. The declared aim of this legislation is the consumers protection against food dangerous for health and/or unfit for consumption, but in the determination of the hazard of food the potential effects of the pollution sources on the safety of the product are not taken into account.

The methodology of the process involves the use of the multicriteria analysis. This analysis, in association with GIS, is widely used as decision-making tool, in the field of environmental quality and land management [13]. Several examples can be cited, in various contexts, such as perimeters for the creation of protected areas [14], touristic areas [15] [16], flooding risk areas [17] [18], landfill site selection [19] and so on.

Aim of this work was to define a procedure for the calculation of an environmental Precaution Index. The index, considering all the main potential pollution sources, general or specific for a particular food (e.g., dairy products), has the aim to summarize in a single value the environmental situation of the territory where it is calculated, and to map it. The final result is the creation of a digital database on pollution sources in a given area, which can be used as a whole or for the part that affects a specific aspect. Thus this protocol of existing data elaboration may be used for other applications in the same field.

The paper is divided in two parts: the first describes the procedure to realize the map, in the second there is an application of the methodology in a region of Northern Italy on milk production, as a case study.

\section{Methodology}

A procedure to calculate the Precaution Index was elaborated, analyzing the environmental pollution sources and their influences on agricultural and livestock's products in the geographical area of interest. The flowchart of Figure 1 summarizes the logical process to build the index, calculate and map it. The protocol is developed following several steps, as listed below.

\subsection{Collection and Managing of Data}

Many different types of potential anthropogenic pollution sources are identified and geo-referenced, creating a geo-database managed in a GIS environment (ArcGis 9.1). All the collected data comes from EU and Italian public services. Each category of pollution source is an information layer for the GIS software.

\subsection{Elaboration of the Informative Layers thought the Multicriteria Analysis}

Data elaboration is conducted using the Analytic Hierarchy Process (AHP) method [20] [21], which is a multi- 


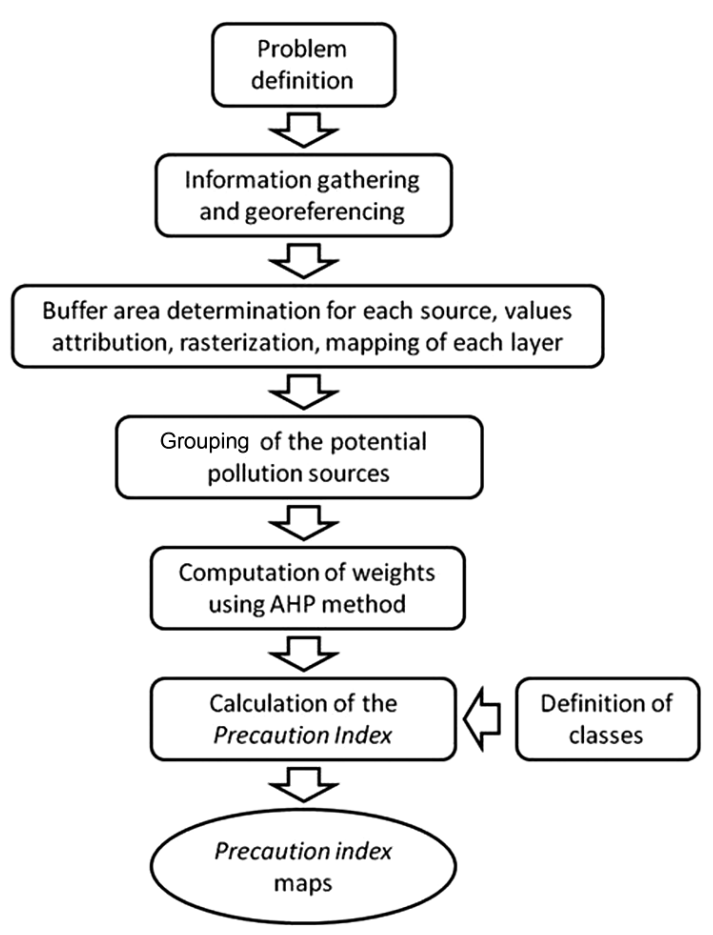

Figure 1. Flowchart for the preparation of a Precaution Index map.

criteria analysis (MCA).

The method allows the treating of different criteria (the pollution sources in this specific case), functional for the same purpose, creating a hierarchy of importance. This is quantified through a system of pairwise comparisons, and gives as a result the weight to assign to each criterion (called also element). The attribution of the values relies on a specific scale of importance later described in details. Pairwise comparisons are based on the best information available, and on the decision maker knowledge and experience. The "AHP" method is performed thanks to a specific module (extension) through the ArcGis 9.1 software [22].

\subsection{Realization of the Maps of the Precaution Index}

Once the weights are assigned to the various layers of information (criteria), i.e. to the types of pollution sources, it is possible to complete the process described previously. The layers of information are added together, thus generating the final information layer that represents the Precaution Index (P):

$$
\mathrm{P}=\sum \mathrm{xi} \cdot \mathrm{wi}, \mathrm{i}=1, \cdots, \mathrm{n}
$$

where,

$\mathrm{xi}=$ value of this $\mathrm{i}$-th criterion.

wi $=$ weight of this i-th criterion.

$\mathrm{n}=$ number of the considered criteria.

$\mathrm{P}$ takes into account both the potential hazard of the source (weight) and its presence (the sum of the layers). The $P$ value mapped at the end of this procedure is encoded on the basis of increasing intensity of precaution. Finally, $\mathrm{P}$ values are clustered in intervals of precaution intensity, so to define areas with negligible precaution till areas that needs maximum precaution.

\subsection{Evaluation of the Judgment Consistency}

The AHP also provides measures to evaluate the consistency of judgments, using an algorithm. Based on the properties of reciprocal matrices, a Consistency Ratio (CR) can be calculated. This process is automatically performed by the ArcGis 9.1 plus AHP software. This passage is necessary for the recognized human limitations in 
establishing, simultaneously, many relationships between objects or concepts in a logical manner [21]. Consequently, this method is used to identify what is the degree of inconsistency of the process performed, and accept or refuse it. A CR of the order of 0.10 or less is a reasonable level of consistency [20], while a consistency ratio above 0.10 requires revisions of judgments in the matrix because of some inconsistent treatment in the rating of at least one of the factors involved.

\section{Application to a Case Study: The Emilia-Romagna Region}

\subsection{Studied Area}

The Precaution Index was calculated for the Emilia-Romagna region (Figure 2), an area of about 22,450 km², located in the North Italy, a highly industrialized territory. From the geographical point of view the area is constituted by the Apennines in the southern side, the Po valley in the central and northern part and borders with the Adriatic sea to the East. The Po valley is characterized by flatlands and superficial watertable, and is very suitable for agriculture, livestock and dairy industry. In fact, this is the production area of the Parmigiano Reggiano cheese, the Parma ham (Parma and Reggio Emilia provinces) and the balsamic vinegar (Modena province), food products famous and popular all over the world.

Other than agricultural activity, Emilia-Romagna is one of the most developed and productive area of the country. A high specialization of the industrial areas is quite common, like in the provinces of Ravenna and Ferrara, where there are many chemicals companies in a few square kilometres (Figure 3).

\subsection{Application to Cow's Milk Production and Results}

As an example of the described methodology, the Precaution Index was calculated for cow's milk production, strategic product for the Emilia-Romagna economy.

The trace element and mineral concentrations in milk may be influenced by two kind of factors, some related to the secretion from the mammary gland (lactation state, health status, animal species) and others not depending on cow but to external such as season, nutritional status of the cow, and environment [23] [24]. International literature reports that the environment (e.g. soil type, location of the farm, etc.) interferes with the quality of milk [25]-[30], and there are studies that have examined correlations of elements contained in milk and cows' feed [31]-[33].

In the study area, as affirmed by farmers, cows are mostly fed with forage, cultivated from fields adjacent to the stables. It is therefore realistic that, in presence of pollution sources near the cultivated fields, the forage for the cows can be contaminated by harmful substances, which can then reach the milk, affecting its safety.

The map of Precaution Index individuates which areas are most at risk of potential pollution for milk. For this purpose the sources of pollutants that could be deposited on forage, the beginning of the milk chain, have been identified. This choice has been carried out through consultation with technical experts in the sector of milk quality and taking into account recent papers on the relations between pollutants and cow's milk [24] [32]-[36].

In Emilia-Romagna thirteen sources of environmental pollution were identified as potentially harmful for milk safety: incinerators, landfills, nuclear sites, sites of national interest-SIN (contaminated area), cement factories, roads of major communication, urban areas (later merged with the main roads in a single layer), foundries, chemical plants, treatment and coating of metals industries, waste treatment sites, petrochemical plants (including refineries), industrial and commercial areas, as called in CORINE land use map, and natural gas power plants (in the region this is the only type of power plant). Table 1 shows the list of the data sources.

Precaution Index P was calculated as following:

1) Georeferencing of pollution sources;

2) Creation of areas of influence of pollution sources;

3) Assignment of consistent values to the various categories of pollution sources;

4) Grouping of pollution sources in macro-categories;

5) Pairwise comparison of sources to calculate weight of each macro-category;

6) Calculation and mapping of the Precaution Index.

In details the steps are:

1) The identified potential pollution sources were geo-referenced, using the digital cartographic base (topographic maps at the scale 1:250,000, Table 2), each category in a single layer. Figure 3 shows an example of 


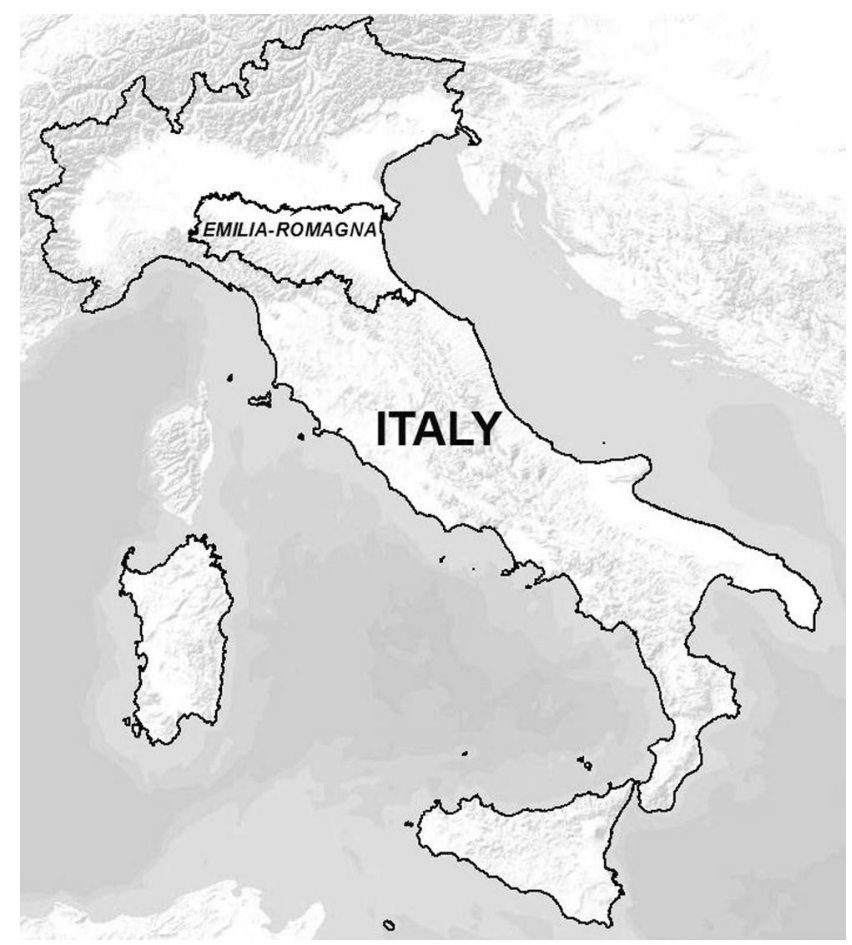

Figure 2. The study area: the Emilia-Romagna region.

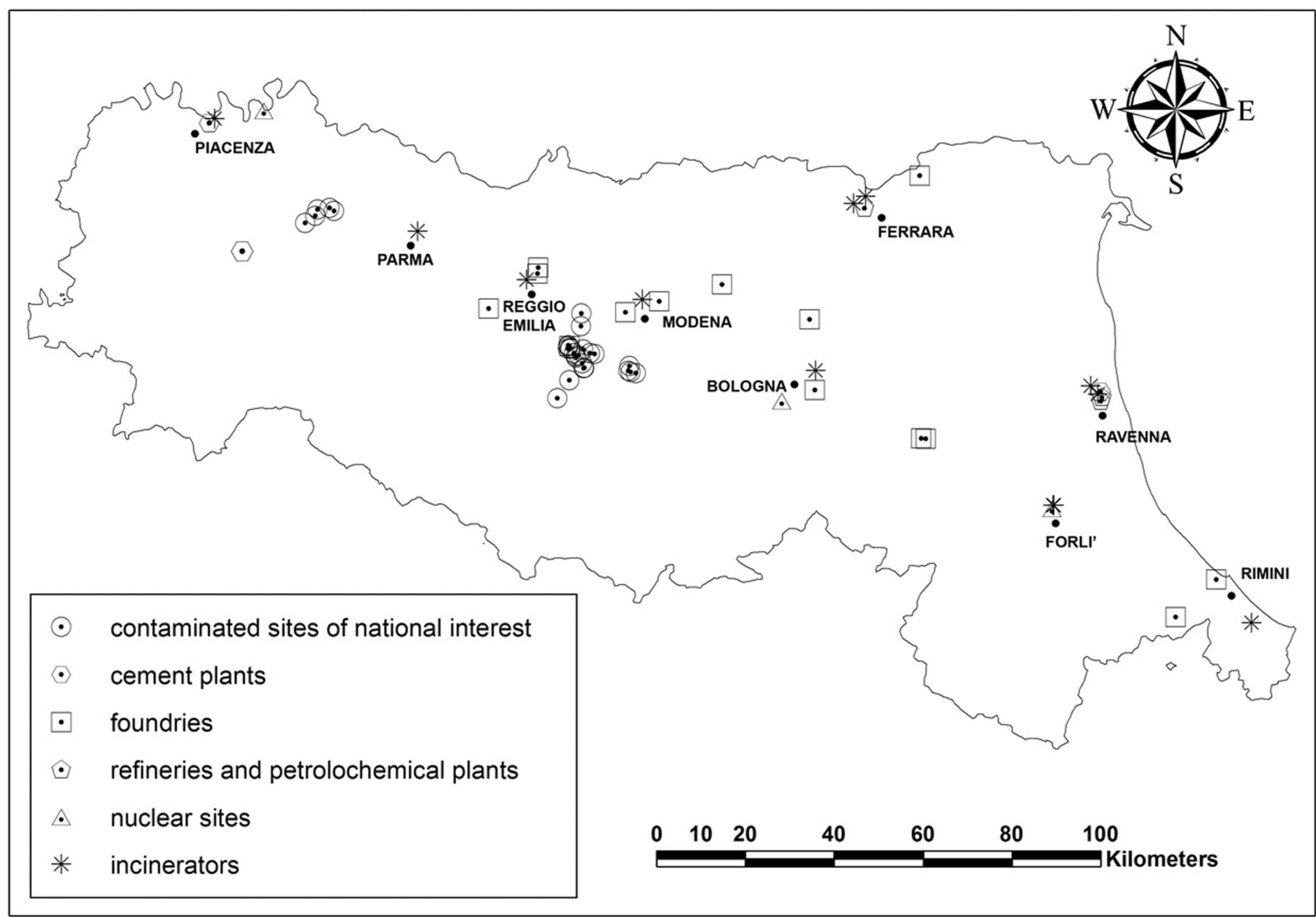

Figure 3. Thematic map representing the distribution of sites of national interest (SIN), cement plants, foundries, incinerators, petrochemical plants and refineries and nuclear sites in Emilia-Romagna region. 
Table 1. List of data sources used to gather information and produce thematic maps of the possible sources of pollutants, generated specifically for this study case.

\begin{tabular}{|c|c|}
\hline Potential pollution sources & Data sources \\
\hline Cement plants & $\begin{array}{l}\text { AITEC associazione italiana tecnico economica cemento,www.aitecweb.com } \\
\text { - AIA Autorizzazione integrata ambientale, www.aia.minambiente.it }\end{array}$ \\
\hline Chemical industries & $\begin{array}{l}\text { - European pollutant release transfer register, www.prtr.ec.europa.eu } \\
\text { - Ministero dell’Ambiente, inventario nazionale degli impianti a rischio rilevante di } \\
\text { incidente, } \\
\text { - AIA Autorizzazione integrata ambientale, www.aia.minambiente.it }\end{array}$ \\
\hline $\begin{array}{l}\text { Contaminated sites of national interest } \\
\text { (SIN) }\end{array}$ & $\begin{array}{l}\text { ISPRA (Istituto Superiore Protezione e Ricerca Ambientale) } \\
\underline{\text { www.isprambiente.gov }}\end{array}$ \\
\hline Foundries & $\begin{array}{l}\text { - European pollutant release transfer register, www.prtr.ec.europa.eu } \\
\text { - Ministero dell’Ambiente, inventario nazionale degli impianti a rischio rilevante di } \\
\text { incidente, } \\
\text { - AIA Autorizzazione integrata ambientale, www.aia.minambiente.it }\end{array}$ \\
\hline Incinerators, Waste to Energy Plants & $\begin{array}{l}\text { - Hera spa, www.gruppohera.it } \\
\text { - ARPA Emilia-Romagna, www.arpa.emr.it } \\
\text { - European pollutant release transfer register, } \underline{\text { www.prtr.ec.europa.eu }} \\
\text { - AIA Autorizzazione integrata ambientale, } \underline{\text { www.aia.minambiente.it }}\end{array}$ \\
\hline Landfill sites & $\begin{array}{l}\text { - Arpa Emilia-Romagna direzione tecnica, gestione integrata rifiuti, } \\
\text { - AIA Autorizzazione integrata ambientale, www.aia.minambiente.it }\end{array}$ \\
\hline Nuclear sites & $\begin{array}{l}\text { - ENEA, Ente per le Nuove tecnologie, l'Energia e l'Ambiente, www.enea.it, revisione } \\
\text { critica dell'inventario nazionale dei rifiuti radioattivi ai fini dello smaltimento. }\end{array}$ \\
\hline Petrochemical plants (including refineries) & $\begin{array}{l}\text { - European pollutant release transfer register, www.prtr.ec.europa.eu } \\
\text { - Ministero dell’Ambiente, inventario nazionale degli impianti a rischio rilevante di } \\
\text { incidente, } \\
\text { - AIA Autorizzazione integrata ambientale, www.aia.minambiente.it }\end{array}$ \\
\hline Roads of major communication & Digitalization of the $1: 250,000$ road maps \\
\hline $\begin{array}{l}\text { Thermal power plants } \\
\text { (both natural gas and oil/coal) }\end{array}$ & $\begin{array}{l}\text { European pollutant release transfer register, www.prtr.ec.europa.eu } \\
\text { - AIA Autorizzazione integrata ambientale, aia.minambiente.it }\end{array}$ \\
\hline Treatment and coating of metals industries & $\begin{array}{l}\text { - European pollutant release transfer register, www.prtr.ec.europa.eu } \\
\text { - Ministero dell’Ambiente, inventario nazionale degli impianti a rischio rilevante di } \\
\text { incidente } \\
\text { - AIA Autorizzazione integrata ambientale, www.aia.minambiente.it }\end{array}$ \\
\hline Urban, commercial craft areas & CORINE land use map \\
\hline Waste treatment plants & $\begin{array}{l}\text { - European pollutant release transfer register, www.prtr.ec.europa.eu } \\
\text { - Hera spa, www.gruppohera.it } \\
\text { - AIA Autorizzazione integrata ambientale, www.aia.minambiente.it }\end{array}$ \\
\hline
\end{tabular}

Table 2. Cartographic themes acquired.

\begin{tabular}{lccc}
\hline \multicolumn{1}{c}{ Acquired Cartography } & Format & Reference system & Data sources \\
\hline $\begin{array}{l}\text { Topographic Maps 1:250,000 } \\
\begin{array}{l}\text { Administrative boundaries } \\
\text { - Region }\end{array}\end{array}$ & Raster: TIF & Gauss-Boaga & Regional mapping service \\
- Provinces & Vectorial: & UTM ED 50 & ISTAT (Italian National Institute of Statistics) \\
- Municipality & Shapefile.shp & & \\
\begin{tabular}{l}
$\begin{array}{l}\text { CORINE land use map and } \\
\text { derived thematic areas, mainly } \\
\text { industrial/commercial areas }\end{array}$ \\
\hline
\end{tabular} & $\begin{array}{c}\text { Vectorial: } \\
\text { Shapefile.shp }\end{array}$ & UTM ED 50 & http://www.centrointerregionale-gis.it/script/corinedownload.asp \\
\hline
\end{tabular}

thematic map, reporting the distribution of some potential pollution source (SIN, cement plants, foundries, incinerators, petrochemical plants and refineries and nuclear sites).

2) For each single source-point georeferenced in each category, an area of potential influence, called buffer area, is created. The radius of influence of each type of pollutant source is evaluated using information found in 
the scientific literature. The buffer area and the main pollutants of each source were listed in Table 3. Lacking direct measurements of impact of each specific source in the studied area, data come mainly from literature [7] [37]-[54]. In case there was literature discrepancy in the influence radius of a particular potential pollutant source, a caution criterion was chosen selecting the largest among those cited. The area of influence was approximated to a circle, (with the exception of roads where it was linear), not being able to go into characteristic details of every single location (winds, geomorphology, etc.).

3) For each buffer area consistent values (x) are assigned:

$\mathrm{x}=1$ within the buffer $(1=$ presence of pollutant source $)$,

$\mathrm{x}=0$ outside the buffer $(0=$ absence of pollutant source $)$.

In case of overlapping of buffers within the same category (e.g., the buffers of two chemical industries close one to the other) a common value is attributed to the union of the two buffer areas, with a value averaged using the area of the union (similarly to a density of population). Each buffer is then converted from vector to raster format (matrix of cells with $250 \mathrm{~m}$ size) for application in the AHP module of ArcGis. During this procedure the $\mathrm{x}$ values, attributed to the buffer in the previous step, are transformed to the closest integer.

4) After all the single sources were mapped, they were grouped by the relevance on the potential risks in milk safety. Considering that for the pair comparison Saaty [20] suggested that the number of elements compared must be small than nine, sources were clustered into four macro-categories (called criteria for the AHP analysis). Table 4 summarizes the grouping. This part of the process was carried out with the help of staff with specific knowledge in dairy industry and milk safety. Based on these indications, the following pollutants were taken into account: dioxins (PCDD and PCDF), PCBs, dioxin-like PCBs, PAHs, heavy metals, pesticides, radionuclides, and organic solvents. Sources considered as similar potential impact on milk have the same ranking. A caution attitude was chosen at this decision level.

The grouping in macro-categories is the following:

a) the first macro-category (C1) comprised the sites of national interest—SIN , recognized as actually polluted areas by ministerial decrees. They were considered at the top of the ranking, compared to other sources that are "only" potentially polluting;

b) the second macro-category (C2) comprised the nuclear sites, because of the potential hazard of radionuclides, and cement plants, foundries, incinerators, petrochemical plants and refineries, grouped for the similarity of their pollutants (dioxin, PCBs, PAHs and heavy metals, radionuclides) and their typical large size;

c) the third macro-category (C3) included landfills, treatment and coating of metals industries and waste treatment sites. From the milk safety point of view, they emit heavy metals and organic solvents, that may be released in soil and superficial water-bodies. This group includes chemicals industries too, that means a wide range of products (e.g. fertilizers, detergents, paints, etc.), with different environmental impact (site-specific) and facilities production capacity. Not being able to going into too much detail and given the variety of emissions, chemical industries have been attributed to $\mathrm{C} 3$, thus mediating their potential dangers;

d) the fourth macro-category (C4) included thermal power plants (natural gas), urban and commercial-industrial areas and roads. All these sources emit heavy metals at low concentration (traces) than the previous sources into the atmosphere.

5) Pairwise comparison of the sources and calculation of their weights, or multiplying factors, account for the dangerousness of potential pollution sources. The weights assignment is done through the AHP module, which, as mentioned above, requires the compilation of a table of pairwise comparisons, where each category is compared with all the others. For this phase the "fundamental scale of Saaty" [21] (Table 5) is used, which help to indicate how many times more important or dominant one element is over another. This scale consists of nine values, the numerousness was selected because psychologists suggest that nine is the maximum quantity of objects that an individual can simultaneously compare and consistently rank [20]. The whole process is summarized in Figure 4.

As seen above, in parallel with the calculation of the weights, the AHP method provides the calculation of data necessary for checking the internal consistency of the matrix, i.e. of its reliability, by means of the consistency ratio CR. The statistical results showed that the hierarchical tree was consistent $(\mathrm{CR}<0.10)$, guaranteeing the use of the values generated for the $\mathrm{P}$ calculation.

6) When calculated, $P$ assumes continuous values, ranging from zero to a maximum. These values identify the areas with the highest potential pollution, corresponding to the highest precaution needs. All $\mathrm{P}$ values were then reclassified on the basis of increasing intensity of precaution in a scale from 0 to 4 , with $0=$ negligible precau- 
Table 3. Potential sources of pollution, their estimated buffer areas (fall-out or ground infiltration), and their main pollutants for milk production.

\begin{tabular}{ccc}
\hline Pollution sources & Radius $\mathbf{( k m )}$ & Main pollutant \\
\hline Sites of national interest (SIN) & 2 & Site-specific pollutant, typically industrial waste \\
Cement plants & 5 & \\
Foundries & 5 & \\
Incinerators, waste-to-energy plants & 5 & Dioxin, PCBs, PAHs, heavy metals, radionuclides \\
Petrochemical plants including refineries & 5 & \\
Nuclear sites & 2 & \\
Treatment and coating of metals industries & 3 & Heavy metal, organic solvents \\
Landfills sites & 2 & \\
Waste treatment sites & 3 & \\
Chemical industries & 3 & Heavy metal and other non-individually specifiable \\
Thermal power plants (natural gas) & 5 & \\
Roads of major communication and urban areas & 0.25 & \\
Commercial-industrial areas & 0.25 & \\
\hline
\end{tabular}

Table 4. Grouping of pollution sources in to macro-categories (criteria), taking into account the type of emissions and the impact on milk, and weights calculated through the Analytic Hierarchy Process.

\begin{tabular}{|c|c|c|}
\hline Pollution sources & Criteria & Weights (wi) \\
\hline Sites of national interest (SIN) & $\mathrm{C} 1$ & 0.5831 \\
\hline \multicolumn{3}{|l|}{ Cement plants } \\
\hline \multicolumn{3}{|l|}{ Foundries } \\
\hline Incinerators, waste-to-energy plants & $\mathrm{C} 2$ & 0.2895 \\
\hline \multicolumn{3}{|l|}{ Petrochemical plants (including refineries) } \\
\hline \multicolumn{3}{|l|}{ Nuclear sites } \\
\hline \multicolumn{3}{|l|}{ Treatment and coating of metals industries } \\
\hline \multicolumn{3}{|l|}{ Landfills sites } \\
\hline \multicolumn{3}{|l|}{ Waste treatment sites } \\
\hline \multicolumn{3}{|l|}{ Chemical industries } \\
\hline \multicolumn{3}{|l|}{ Thermal power plants (natural gas) } \\
\hline Roads of major communication and urban areas & C4 & 0.0425 \\
\hline Commercial-industrial areas & & \\
\hline
\end{tabular}

Table 5. Relative scale used in the construction of pair-wise comparison matrices (modified from Saaty, 2008). For populating the pair-wise comparison matrix, numbers are used to represent the relative importance of one criterion over another and derive the weights accorded to the different categories of sources.

\begin{tabular}{cc}
\hline Intensity of importance & Description \\
\hline 1 & Equal importance \\
3 & Moderate importance \\
5 & Strong importance \\
7 & Very strong or demonstrated importance \\
9 & Extreme importance \\
$2,4,6,8$ & Intermediate values \\
$1 / 3,1 / 5,1 / 7,1 / 9$ & Values for inverse comparison \\
\hline
\end{tabular}




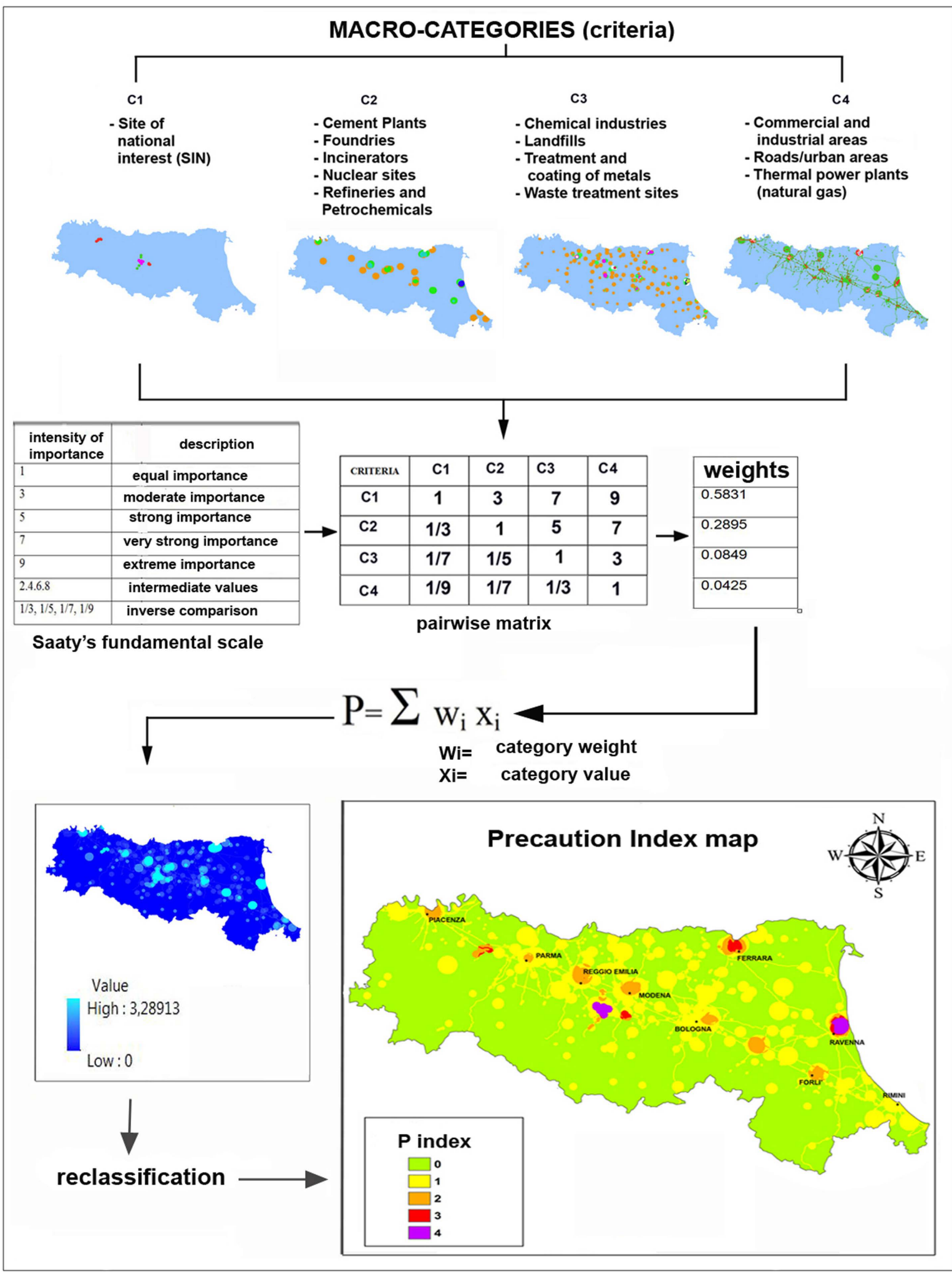

Figure 4. Summary of the whole process: first the maps for each criteria, comparison by means of the pairwise process of all the potential criteria and the resulting Precaution Index map, obtained after the calculation of weights and final processing. Please note that $0=$ negligible precaution; $1=$ minimum precaution; $2=$ moderate precaution; $3=$ high precaution and 4 = maximum precaution. 
tion; 1 = minimum precaution; 2 = moderate precaution; $3=$ high precaution and $4=$ maximum precaution. Following that cluster precaution interval, in Emilia-Romagna region (Figure 4) the P = 0 in most part of the region, precisely in the $75 \%$ of the total area, indicating that in most of the territory there is no potential risk for milk safety, while $\mathrm{P}=1$ in the $22 \%, \mathrm{P}=2$ in the $2 \%, \mathrm{P}=3$ in the $0.5 \%$ and $\mathrm{P}=4$ in the last $0.5 \%$. Most of the area with negligible precaution corresponds to the mountain (Apennines). The areas with maximum precaution $(\mathrm{P}=4)$ are next to Modena and Ravenna towns: in fact as visible from Figure 3, these are areas with important pollutant sources. Specifically, the first is related to the SIN of Sassuolo (MO), while the second represents an area with high concentration of pollutant sources, in particular petrochemical and refinery plants, cement plant and clustered chemicals plants.

\section{Discussion and Conclusions}

Until recently the effect of the surrounding environment on food products, such as milk, has not been adequately taken into account. Some studies deal with the contamination on the milk by specific pollutants from specific sources [24] [33] [36], but none addresses the problem of environmental pollution as a whole, although it is an important topic, taking into account also the expansion of peri-urban agriculture.

Considering simultaneously all the involved variables is extremely complex: $\mathrm{P}$ computation derives from a simplification of the reality, which, however, have the advantage to make the methodology generalizable. One of these simplifications is the description of the area from a static point of view. Of course, the study could be refined with further research, such as introducing the study of prevailing winds and orography; and it would be useful to define in more details the buffer areas; and this may be done in the future. Overall, it is impossible to know the pollution sources in more detail, as this would require lengthy and costly monitoring campaigns for each one, but this would be possible in case of application in smaller areas and to respond to very precise queries. Hence, in general the map of Precaution Index aims to highlight which areas are most at risk (hotspots) and to direct the investigation: the knowledge of potential environmental risks, and of the pollutants that may be involved, is very useful to drive national and regional authorities in deciding if a monitoring is necessary, and which substances may be involved. This may help in the early identification of emerging hazards to food safety [54]-[56], with the aim of preventing them from becoming real risks and causing the reduction of food quality.

In addition, this procedure can be very useful for farmers and food companies: through this map they may know if their product could be potentially contaminated, and eventually address more efficiently the processes of quality control on their product. As an example, the showed case study of milk in Emilia-Romagna region highlights the presence of some hotspots, where the presence of pollution sources (for type or quantity) makes the surroundings potentially at risk of contamination. Therefore, this result suggests that these areas should be subject to intensified inspection and monitoring, and that milk coming from stables located within or near a hotspot should be liable to specific control to verify if contamination occurred on feed and therefore on milk.

The main aspect of the described process is its versatility: it can be applied in various fields and for very different purposes. It is possible to adapt the system, paying particular attention to two points, the choice of the potential pollution sources and the relative importance among the sources. In fact, the reciprocal importance of the selected sources (and sometimes the sources themselves) can vary for different applications, such as food safety in general, organic production, milk quality, DOP, DOC and other special titles that characterize Italian food products, and so on. These decisions must be made by specific experts and consulting the international and local literature.

\section{Acknowledgements}

We warmly thank Dr. Andrea Borsari and his staff for their precious advices and expert recommendations. This project was founded by Granarolo S.p.A.

\section{References}

[1] The European Environment-State and Outlook 2010. http://wwweeaeuropaeu/soer

[2] Marshall, F.M. and Te-Lintelo, D.T.H. (2001) Pollution Effects: Social and Economic Implications of Urban and Peri-Urban Agriculture in India. Urban Agriculture Magazine, 5 Leusden.

[3] Jager, H. J., Unsworth, M.H., De Temmerman, L. and Mathy, P. (1993) Effects of Air Pollution on Agricultural Crops 
in Europe Air Pollution Research Report 46. Commission of the European Communities, Brussels Belgium.

[4] Ashmore, M.R. and Marshall, F.M. (1999) Ozone Impacts on Agriculture: an Issue of Global Concern. Advances in Botanical Research, 29, 32-49.

[5] Agrawal, M., Singh, B., Rajput, M., Marshall, F. and Bell, J.N.B. (2003) Effect of Air Pollution on Peri-Urban Agriculture: A Case Study. Environmental Pollution, 126, 323-329.

[6] Te-Lintelo, D.T.H., Marshall, F.M. and Bhupal, D.S. (2002) Urban Food: The Role of Urban and Peri Urban Agriculture in India: A Case Study from Delhi. Food Nutrition and Agriculture, 29, 4-13.

[7] Capuano, F., Cavalchi, B., Martinelli, G., Pecchini, G., Renna, S.E.I., Bertacchi, M. and Bigliardi, G. (2005) Environmental Prospection for PCDD/PCDF PAH PCB and Heavy Metals in the Incinerator Power Plant of Reggio Emilia Town (Northern Italy) and Surrounding Main Roads. Chemosphere, 58, 1563-1569.

[8] Nadal, M., Schuhmacher, M. and Domingo, J.L. (2007) Levels of metals PCBs PCNs and PAHs in Soils of a Highly Industrialized Chemical/Petrolchemical Area: Temporal Trend. Chemosphere, 66, 267-276.

[9] Novotny, V. (1999) Diffuse Pollution from Agriculture. A Worldwide Outlook. Water Science and Technology, 39, $1-13$.

[10] D’Arcy, B. and Frost, A. (2001) The Role of Best Management Practices in Alleviating Water Quality Problems Associated with Diffuse Pollution. Science of the Total Environment, 265, 359-367.

[11] Collins, A.L. and McGonigle, D.F. (2008) Monitoring and Modelling Diffuse Pollution from Agriculture for Policy Support. UK and European Experience Environmental Science \& Policy, 11, 97-101.

[12] Iital, A., Pachel, K. and Deelstra, J. (2008) Monitoring of Diffuse Pollution from Agriculture to Support Implementation of the WFD and the Nitrate Directive in Estonia. Environmental Science \& Policy, 11, 185-193.

[13] Banai-Kashani, A.R. (1989) New Method for Site Suitability Analysis-The Analytic Hierarchy Process. Environmental Management, 13, 685-693.

[14] Candura, A., Dal Sasso, P. and Marinelli, G. (2009) Analisi Multi Criteri e GIS per la Facilitazione Delle Scelte di Pianificazione. Atti del IX Convegno Nazionale Associazione Italiana Ingegneria Agraria Ischia Porto, Ischia Porto, 12-16 Settembre 2009, 13 Pages.

[15] Aprile, A. (2008) Un’applicazione GIS per la realizzazione di una carta di vocazione agrituristica nel territorio leccese MTISD. Methods Models and Information Technologies for Decision Support Systems Università del Salento Lecce 18-20 September 2008, 91-94.

[16] Ghamgosar, M., Haghyghy, M., Mehrdoust, F. and Arshad, N. (2011) Multicriteria Decision Making Based on Analytical Hierarchy Process (AHP) in GIS for Tourism. Middle East Journal of Scientific Research, 10, 501-507.

[17] Cherubini, C., Orlando, G., Reina, A. and Torre, C.M. (2006) La sinergia tra analisi multicriteriale (AMC) e GIS nella valutazione del rischio di esondazione: Il bacino della lama Baronale-Picone (Ba). Giornale di Geologia Applicata, 3 , 109-113.

[18] Fernandez, D.F. and Lutz, M.A. (2010) Urban Flood Hazard Zoning in Tucuman Province Argentina Using GIS and Multicriteria Decision Analysis. Engineering Geology, 111, 90-98. http://dx.doi.org/10.1016/j.enggeo.2009.12.006

[19] Vasiljevic, T.Z., Sdrjevic, Z., Bajcetic, R. and Miloradov, M.V. (2012) GIS and the Analytic Hierarchy Process for Regional Landfill Site Selection in Transitional Countries: A Case of Study from Serbia. Environmental Management, 49, 445-458. http://dx.doi.org/10.1007/s00267-011-9792-3

[20] Saaty, T.L. (1980) The Analytic Hierarchy Process. McGraw-Hill, New York.

[21] Saaty, T.L. (2008) Decision Making with the Analytic Hierarchy Process. International Journal of Services Sciences, 1, 83-98.

[22] Marinoni, O. (2004) Implementation of the Analytical Hierarchy Process with VBA in ArcGis. Computers \& Geosciences, 30, 637-646. http://dx.doi.org/10.1016/j.cageo.2004.03.010

[23] O’Brien, B., Mehra, R., Connolly, J.F. and Harrington, D. (1999) Seasonal Variation in the Composition of Irish Manufacturing and Retail Milks 4 Minerals and Trace Elements. Irish Journal of Agricultural and Food Research, 38, 97-99.

[24] Sola-Larrañaga, C. and Iñigo Navarro-Blasco, I. (2009) Chemometric Analysis of Minerals and Trace Elements in Raw Cow Milk from the Community of Navarra Spain. Food Chemistry, 112, 189-196. http://dx.doi.org/10.1016/j.foodchem.2008.05.062

[25] Orak, H., Yanardag, R. and Hugul, M. (2000) The Levels of Sodium Potassium Magnesium and Calcium in Various Milk Samples of Turkey. Food/Nahrung, 44, 285-287. http://dx.doi.org/10.1002/1521-3803(20000701)44:4<285::AID-FOOD285>3.0.CO;2-A

[26] Rodríguez, E.M., Sanz, M. and Díaz, C. (2001) Mineral Concentrations in Cows’ Milk from the Canary Island. Journal 
of Food Composition and Analysis, 14, 419-430. http://dx.doi.org/10.1006/jfca.2000.0986

[27] Lante, A., Lomolino, G., Cagnin, M. and Spettoli, P. (2004) Content and Characterisation of Minerals in Milk and in Crescenza and Squacquerone Italian Fresh Cheeses by ICP-OES. Food Control, 17, 229-233. http://dx.doi.org/10.1016/j.foodcont.2004.10.010

[28] Licata, P., Trombetta, D., Cristani, M., Giofre, F., Martino, D., Calo, M., et al. (2004) Levels of “Toxic” and "Essential” Metals in Samples of Bovine Milk from Various Dairy Farms in Calabria Italy. Environmental International, 30, 1-6. http://dx.doi.org/10.1016/S0160-4120(03)00139-9

[29] Dobrzarnski, Z., Kolacz, R., Górecka, H., Chojnacka, K. and Bartkowiak, A. (2005) The Content of Microelements and Trace Elements in Raw Milk from Cows un the Silesian Region. Polish Journal of Environmental Studies, 14, 685689.

[30] Hermansen, J.E., Badsnerg, J.H., Kristensen, T. and Gundersen, V. (2005) Major and Trace Elements in Organically or Conventionally Produced Milk. Journal of Dairy Research, 72, 362-368. http://dx.doi.org/10.1017/S0022029905000968

[31] Coni, E., Caroli, S., Ianni, D. and Bocca, A. (1994) A Methodological Approach to the Assessment of Trace Elements in Milk and Dairy Products. Food Chemistry, 50, 203-210. http://dx.doi.org/10.1016/0308-8146(94)90121-X

[32] Coni, E., Bocca, A., Ianni, D. and Caroli, S. (1995) Preliminary Evaluation of the Factors Influencing the Trace Element Content of Milk and Dairy Products. Food Chemistry, 52, 123-130. http://dx.doi.org/10.1016/0308-8146(94)P4190-Q

[33] Simsek, O., Gültekin, R., ÖKsüz, O. and Kurultay, S. (2000) The Effect of Environmental Pollution on the Heavy Metal Content of Raw Milk. Food/Nahrung, 44, 360-363. http://dx.doi.org/10.1002/1521-3803(20001001)44:5<360::AID-FOOD360>3.0.CO;2-G

[34] Muñiz-Naveiro, O., Domínguez-González, R., Bermejo-Barrera, A., Cocho de Juan, J.A., Fraga Bermúdez, J.M., Goris Pereiras, A., et al. (2005) Selenium Content and Distribution in Cows' Milk Supplemented with Two Dietary Selenium Sources. Journal of Agricultural and Food Chemistry, 53, 9817-9822. http://dx.doi.org/10.1021/jf050155w

[35] Concannon, C. (2005) Dioxin Levels in the Irish Environment A Third Assessment (Summer 2004) Based on Levels in Cows’ Milk Environmental Protection Agency Wexford Ireland. http://www.epa.ie/pubs/reports/other/dioxinresults/EPA_dioxin_levels_in_the_irish_environment_2004.pdf

[36] O’Donovan, J.V., O’Farrell, K.J., O’Mahony, P. and Buckley, J.F. (2011) Temporal Trends in Dioxin Furan and Polychlorinated Biphenyl Concentrations in Bovine Milk from Farms Adjacent to Industrial and Chemical Installations over a 15-Year Period. The Veterinary Journal, 190, 117-121. http://dx.doi.org/10.1016/j.tvjl.2011.02.024

[37] Anderson, V.R. and Fisher, R. (2002) Sources of Dioxins in the United Kingdom: The Steel Industry and Other Sources. Chemosphere, 46, 371-381. http://dx.doi.org/10.1016/S0045-6535(01)00178-3

[38] ARPAV Veneto Dipartimenti Provinciali di Padova e Treviso (2009) Modellistica di dispersione degli inquinanti atmosferici dal Cementificio Rossi di Pederobba (Treviso). Sintesi non tecnica del documento prodotto dall’Osservatorio Regionale Aria ARPAV (prot n 126686 del 14/10/2009).

[39] Ba, T., Zheng, M., Zhang, B., Liu, W., Xiao, K. and Zhang, L. (2009) Estimation and Characterization of PCDD/Fs and Dioxin-Like PCBs from a Secondary Copper and Aluminium Metallurgies in China. Chemosphere, 75, 1173-1178. http://dx.doi.org/10.1016/j.chemosphere.2009.02.052

[40] Boraldi ,V. and Captano, F. (2010) Gestione ambientale nel distretto ceramica. Ecoscienza, 3, 116-117.

[41] EniPower (2006) Dichiarazione Ambientale-Stabilimento di Ferrera Erbognone.

[42] Franzaring, J., Hrenn, H., Schumm, C., Klumpp, A. and Fangmeier, A. (2006) Environmental Monitoring of Fluoride Emissions Using Precipitation Dust Plant and Soil Samples. Environmental Pollution, 144, 158-165. http://dx.doi.org/10.1016/j.envpol.2005.12.033

[43] Fraternali, D. and Oliveti Selmi, O. (2003) Le emissioni di centrali a ciclo combinato Analisi e confronto con impianti termoelettrici tradizionali. RichMac Magazine, 5, 1-5.

[44] Kalabokas, P.D., Hatzianestis, J., Bartzis, J.G. and Papagiannakopoulos, P. (2001) Atmospheric Concentrations of Saturated and Aromatic Hydrocarbons around a Greek Oil Refinery. Atmospheric Environment, 35, 2545-2555. http://dx.doi.org/10.1016/S1352-2310(00)00423-4

[45] Leonardi, M., Madeo, L., Martini, M.G. and Matteucci, M. (2006) Trattamento dei rifiuti in Campania: Impatto sulla salute umana Messa a punto di indicatori sintetici di pericolosità e di esposizione ai rifiuti. http://www.protezionecivile.it/docs/www.ulpiano11.com/docs/rapportoRifiuti08/RelazioneStudioIndAmb.pdf

[46] Liem, A.K.D., Hoogerbrugge, R., Kootstra, P.R., Van der Velde, E.G. and De Jong, A.P.J.M. (1991) Occurrence of Dioxins in Cow's Milk in the Vicinity of Municipal Waste Incinerators and a Metal Reclamation Plant in the Netherlands. Chemosphere, 23, 1675-1684. http://dx.doi.org/10.1016/0045-6535(91)90016-7 
[47] Neto, B., Kroeze, C., Hordijk, L. and Costa, C. (2009) Inventory of Pollution Reduction Option for Aluminium Pressure Die Casting Plant. Resources Conservation and Recycling, 53, 309-320. http://dx.doi.org/10.1016/j.resconrec.2009.01.003

[48] Pitea, D., Bortolami, M., Collina, E., Cortili, G., Franzoni, F., Lasagni, M. and Piccinelli, E. (2008) Prevention of PCdd/F Formation and Minimization of Their Emission at the Stack of a Secondary Aluminum Casting Plant. Environmental Science Technology, 42, 7476-7481. http://dx.doi.org/10.1021/es800976s

[49] Rapiti-Caputo, D. and Vaccaio, C. (2006) Geochemical Evidences of Landfill Leachate in Groundwater. Engineering Geology, 85, 101-121.

[50] Roorda-Knape, M.C., Janssen, N.A.H., De Hartog, J.J., Van Vlietp, H.N., Harssema, H. and Brunekreef, B. (1998) Air Pollution from Traffic in City Districts near Major Motorways. Atmospheric Environment, 32, 1921-1930. http://dx.doi.org/10.1016/S1352-2310(97)00496-2

[51] Schumacker, M., Granero, S., Xifro, A., Domingo, J.L., Rivera, J. and Eljarrat, E. (1998) Levels of PCDD/Fs in Soil Sample in the Vicinity of the Municipal Solid Waste Incinerator. Chemosphere, 37, 2127-2137. http://dx.doi.org/10.1016/S0045-6535(98)00275-6

[52] Thompson, G., Swain, J., Kay, M. and Forster, C.F. (2001) The Treatment of Pulp and Paper Mill Effluent: A Review. Bioresource Technology, 77, 275-286. http://dx.doi.org/10.1016/S0960-8524(00)00060-2

[53] Tuhackova, J., Cajthaml, T., Novak, K., Novotny, C., Mertelik, J. and Sasek, V. (2001) Hydrocarbon Deposition and Soil Microflora as Affected by Highway Traffic. Environmental Pollution, 113, 225-262. http://dx.doi.org/10.1016/S0269-7491(00)00193-7

[54] Kleter, G.A. and Marvin, H.J.P. (2009) Indicators of Emerging Hazards and Risks to Food Safety. Food and Chemical Toxicology, 47, 1022-1039. http://dx.doi.org/10.1016/j.fct.2008.07.028

[55] Viard, B., Pihan, F., Promeyra, S. and Pihan, J.C. (2004) Integrated Assessment of Heavy Metal (Pb Zn Cd) Highway Pollution: Bioaccumulation in Soil Graminaceae and Land Snails. Chemosphere, 55, 1349-1359. http://dx.doi.org/10.1016/j.chemosphere.2004.01.003

[56] Marvin, H.J.P., Kleter, G.A., Frewewr, L.J., Cope, S., Wentholt, M.T.A. and Rowe, G. (2009) A Working Procedure to Identify Emerging Food Safety Issues at an Early Stage: Implications for European and International Risk Manager Practices. Food Control, 20, 345-356. http://dx.doi.org/10.1016/j.foodcont.2008.07.024 